\begin{tabular}{c} 
PEDIOMATERNAL \\
NURSING JOURNAL \\
Vol. 5, No. 1, Maret 2019 \\
\\
Jediomaternal \\
Journal Homepage: https://e-journal.unair.ac.id/PMN// \\
\hline
\end{tabular}

Original Research

\title{
Analisis Faktor yang berhubungan dengan Pencegahan Stunting pada Anak Usia 2-5 Tahun berdasarkan Teori Health Promotion Model (HPM)
}

\author{
(Factor Analysis Related to the Prevention of Stunting in Children 2-5 Years Old Based on the \\ Health Promotion Model Theory)
}

\author{
Ribka Putri Sholecha, Esti Yunitasari, Ni Ketut Alit Armini dan Yuni Sufyanti Arief
}

Fakultas Keperawatan, Universitas Airlangga, Surabaya, Jawa Timur, Indonesia

\author{
ARTICLE HISTORY \\ Received: March 17, 2019 \\ Accepted: April 20, 2019
}

\section{KEYWORDS}

child; health promotion model; madura; prevention; stunting

\section{CORRESPONDING AUTHOR}

Ribka Putri Sholecha ribka.putri.sholecha2017@fkp.unair.ac.id

Fakultas Keperawatan, Universitas Airlangga, Surabaya, Jawa Timur, Indonesia

\begin{abstract}
Introduction: Indonesia still faced nutritional problems in children is like stunting Stunting is one of conditions of malnutrition in child that need to be solved in Indonesia because it can affect the quality of the next generation. This study aimed to analyze the factors related to prevention of stunting in children based on Theory of the Health Promotion Model (HPM).

Methods: This study used a cross-sectional design. The population was mothers who have children aged 2-5 years with number of samples are 141 people using purposive sampling technique. The independent variables were prior related behavior, education level, socio-economic status, perceived benefits to action and perceived barrier to action. Dependent variable was prevention of stunting. Data were collected using questionnaire and analyzed using logistic regression with a significance level $\alpha<0.05$.

Results: A positive stunting prevention behavior were $66.7 \%$ (94 people). Factors related to stunting prevention behavior were prior related behavior $(\mathrm{p}=0.03)$. While for other independent factors are level of education $(p=0.74)$, socioeconomic status $(p=0.07)$, perceived benefits to action $(p=0.35)$ and perceived barrier to action $(p=0.31)$ have no relationship with stunting prevention. The result of analysis on the prior related behavior had 2.81 times better in stunting prevention with a significance level is 0.03 .

Conclusion: The behavior of stunting prevention is influenced by prior related behavior that is supplementary feeding for pregnant women, overcoming iron and folic acid deficiency, providing worm medicine, providing complete immunization and preventing and treating diarrhea.
\end{abstract}

Sholecha, R, P., Yunitasari, E., Armini, N. K. A., \& Arief, Y. S. (2019). Analisis Faktor yang berhubungan dengan Pencegahan Stunting pada Anak Usia 2-5 Tahun berdasarkan Teori Health Promotion Model (HPM). Pediomaternal Nurs. J., 5(1), 49-56.

\section{PENDAHULUAN}

Stunting adalah salah satu kegagalan mencapai perkembangan fisik yang diukur berdasarkan tinggi badan menurut usia. Batasan stunting yaitu tinggi badan menurut usia berdasarkan Z-score sama dengan atau kurang dari -2 SD di bawah rata-rata standar(1). Indonesia menduduki peringkat kelima dunia untuk jumlah anak dengan kondisi stunting dimana lebih dari sepertiga anak berusia dibawah lima tahun tingginya berada di bawah rata-rata (2). Perilaku pencegahan stunting yang tidak teratasi akan menyebabkan dampak jangka pendek yaitu angka kematian dan kesakitan meningkat dan jangka panjang yaitu penurunan prestasi belajar, kapasitas dan produktifitas kerja (3). Balita pendek atau stunting adalah suatu kondisi pada anak yang gagal tumbuh karena kekurangan zat gizi kronis sehingga menimbulkan anak menjadi lebih pendek untuk usianya. Teori Health Promotion Model menekankan pada peran aktif klien dalam mengatur perilaku sehatnya yang menjelaskan mengenai promosi 
kesehatan yang bertujuan sebagai pencegahan suatu penyakit (5).

Pada tahun 2013 terjadi peningkatan jumlah kasus gizi buruk di Jawa Timur yaitu dari tahun 2012 sebesar 8.410 kasus meningkat menjadi 11.056 kasus. Di Kabupaten Bangkalan pada tahun 2018 terdapat $16,84 \%$ (902 balita) yang mengalami indikator bayi pendek dan sangat pendek dimana paling banyak terjadi di Desa Galis sebanyak 20,6\% (186 balita), Desa Bangkalan sebanyak 12,8\% (116 balita), disusul desa Arosbaya sebanyak 10,7\% (97 balita) (Dinkes Bangkalan, 2018).

Stunting terjadi akibat tidak terpenuhinya gizi kronis di 1000 hari pertama kehidupan yang mengakibatkan perkembangan anak terganggu. Periode emas 1000 hari pertama kehidupan yang tidak bisa tergantikan dimana kebutuhan gizi anak harus terpenuhi sperilaku anak bisa berkembang optimal dan perkembangan otak anak terjadi dengan pesat (6). Anak yang mengalami stunting akan mengurangi kesempatan seorang anak untuk bertahan hidup dan juga menghalangi kesehatan, pertumbuhan dan perkembangan anak yang optimal dimana memiliki konsekuensi berbahaya jangka panjang untuk kemampuan kognitif, kinerja sekolah dan masa depan anak itu sendiri. Stunting dapat menyebabkan kualitas sumber daya manusia yang merupakan aset dan investasi bangsa yang lebih maju menjadi terhambat, produktifitas dan daya saing bangsa juga akan menurun (7).

Perilaku pencegahan stunting menurut (4) bahwa stunting dapat dicegah dengan melakukan inisiasi menyusu dini (IMD), berperilakulah agar bayi mendapat kolostrum air susu ibu (ASI) dan memberikan hanya ASI saja sampai bayi berusia 6 bulan. Sedangkan di Madura masih terdapat perilaku etnik Madura yaitu masih praktik pembuangan kolostrum, pemberian makanan pendamping ASI terlalu dini (kurang dari 6 bulan), kurangnya konsumsi protein hewani dan tidak memperolehnya imunisasi secara lengkap (8). Hal ini menyebabkan stunting di Madura masih tinggi. Tingkat pendidikan ibu dan pendapatan keluarga merupakan faktor yang berhubungan nyata terhadap stunting pada balita(9). Keadaan air bersih, sanitasi yang kurang serta tingkat pendidikan yang rendah menjadi intervensi gizi sensitif yang merupakan perilaku pencegahan stunting melalui 1000 hari kehidupan pertama tidak tercapai, dimana keadaan tersebut menjadikan hambatan dari perilaku pencegahan stunting (10). Teori Health Promotion Model (HPM) menurut Nolla J Pender dimana teori ini untuk mendemonstrasikan hubungan antara manusia dengan lingkungan fisik dan interpersonalnya dalam berbagai dimensi. Pendekatan teori ini berfokus pada kemampuan individu untuk mempertahankan kondisi kesehatannya dengan keyakinan bahwa intervensi yang diberikan lebih baik melakukan tindakan pencegahan penyakit kemudian berusaha untuk melakukan tindakan yang mengarah kepada perbaikan kondisi yang dimilikinya (5). Oleh karena itu, perilaku pencegahan terjadinya stunting menjadi salah satu prioritas untuk dapat menciptakan manusia yang tinggi, sehat, cerdas dan berkualitas.

\section{METODE}

\subsection{Desain}

Penelitian yang dilakukan merupakan jenis penelitian descriptive analitic dengan pendekatan cross sectional.

\subsection{Populasi, sampel, dan sampling}

Populasi merupakan ibu yang memiliki anak usia 2-5 tahun. Jumlah sampel dalam penelitian ini ditentukan berdasarkan Rumus Slovin dan didapat sebanyak 141 orang dengan menggunakan teknik purposive sampling. Kriteria inklusi dalam penelitian ini adaalah bisa membaca dan menulis dan anak dalam keadaan sehat dan tidak mengalami gangguan pencernaan. Kriteria eksklusi dalam penelitian mengalami gangguan mental, anak mengalami kelainan patologis dan anak yang mengalami kelainan kromosom.

\subsection{Variabel}

Variabel independent dalam penelitian adalah perilaku sebelumnya, tingkat pendidikan, status sosial ekonomi, manfaat yang dirasakan dan hambatan terhadap tindakan yang dirasakan serta upaya pencegahan stunting sebagai variabel dependent.

\subsection{Instrumen}

Kuesioner pencegahan stunting terdapat 52 yang dibuat oleh peneliti sendiri dengan mengacu berdasarkan teori Health Promotion Model (HPM). Kuesioner variabel perilaku sebelumnya terdapat 19 pertanyaan, variabel manfaat dari tindakan terdapat 4 pertanyaan, variabel hambatan terhadap tindakan terdapat 22 pertanyaan, variabel perilaku pencegahan stunting memiliki 6 pertanyaan. Setiap item pertanyaan diberikan skor 1 (sangat setuju), 2 (setuju), 3 (tidak setuju) dan 4 (sangat tidak setuju). Kategori baik (76\%-100\%), cukup (56\%-75\%), dan kurang ( $\leq 55 \%)$.

Kuesioner perilaku sebelumnya ini dimodifikasi oleh peneliti yang terdiri dari 19 pertanyaan yang meliputi pemberian makanan tambahan pada ibu hamil $(1,8,4,12)$, mengatasi kekurangan zat besi dan asam folat $(2,9,3,5)$, mengatasi kekurangan iodium $(6,10,7,11)$, menyediakan obat cacing $(18,15)$, memberikan imunisasi lengkap $(13,16)$ dan melakukan pencegahan dan pengobatan diare $(14,19,17)$. Penilaian pernyataan dengan kode 1=sangat tidak setuju, 2=tidak setuju, 3=setuju, $4=$ sangat setuju, lalu peneliti mengkategorikan menjadi 3 kategori yaitu baik, cukup, kurang.

Kuesioner manfaat dari tindakan terdiri dari 4 pertanyaan yang meliputi peningkatan fungsi kognitif, motoric dan bahasa pada anak $(2,1)$ dan menurunkan biaya perawatan anak sakit $(3,4)$. Penilaian pernyataan dengan kode 1 =sangat tidak setuju, 2 =tidak setuju, 3=setuju, 4=sangat setuju, lalu 
peneliti mengkategorikan menjadi 3 kategori yaitu baik, cukup, kurang.

Kuesioner hambatan terhadap tindakan terdiri dari 22 pertanyaan yang meliputi akses pada air bersih dan sanitasi $(1,4,7,9)$, fortifikasi bahan pangan $(3,6,10,13)$, akses kepada layanan kesehatan dan keluarga berencana $(12,5)$, akses jaminan kesehatan nasional $(2,8)$, akses jaminan persalinan universal $(11,15)$, pendidikan pengasuhan pada orang tua $(14,18)$, pendidikan gizi masyarakat $(16,17)$ dan edukasi kesehatan seksual dan reproduksi serta gizi pada remaja $(21,20)$. Penilaian pernyataan dengan kode 1 =sangat tidak setuju, $2=$ tidak setuju, $3=$ setuju, 4=sangat setuju, lalu peneliti mengkategorikan menjadi 3 kategori yaitu baik, cukup, kurang.

Kuesioner perilaku pencegahan stunting terdiri 6 pertanyaan yang meliputi perbaikan pola makan $(1,4)$, pola asuh $(2,5)$ dan perbaikan sanitasi dan air bersih $(3,6)$. Penilaian pernyataan dengan kode 1 =sangat tidak setuju, $2=$ tidak setuju, $3=$ setuju, $4=$ sangat setuju, lalu peneliti mengkategorikan menjadi 2 kategori yaitu positif dan negative.

\subsection{Prosedur}

Adapun langkah-langkah pengumpulan data yaitu dimulai dengan penyusunan skripsi, kemudian mengajukan surat ijin keterangan penelitian dari Fakultas Keperawatan Universitas Airlangga, surat ijin melakukan penelitian kepada Badan Kesatuan Bangsa dan Politik Provinsi Jawa Timur dengan tembusan kepada Badan Kesatuan Bangsa dan Politik Kabupaten Bangkalan yang mengeluarkan surat kepada Dinas Kesehatan Kabupaten Bangkalan. Kemudian, Dinas Kesehatan memberikan pengantar kepada kepala Puskesmas Galis untuk melakukan penelitian. Setelah mendapatkan izin, peneliti menyeleksi responden di wilayah kerja Puskesmas Galis sesuai dengan kriteria inklusi dan kriteria eksklusi yang telah ditetapkan. Responden yang sesuai sudah menjadi subjek dalam penelitian. Penelitian ini dilakukan pada bulan Desember 2018 selama 2 minggu di Desa Galis Madura. Penelitian dilakukan dengan datang ke posyandu desa Galis dan door to door dibantu oleh kader kesehatan setempat. Posyandu di desa Galis mempunyai sistem 5 meja dimana setiap meja mempunyai kekhususan sendirisendiri yaitu pendaftaran balita, ibu hamil dan menyusui, penimbangan balita, pencatatan hasil penimbangan, penyuluhan dan pelayanan gizi bagi ibu balita, ibu hamil dan ibu menyusui, dan pelayanan kesehatan KB dan imunisasi.

Sebelum dibagikan kuesioner, peneliti menjelaskan terlebih dahulu kepada calon responden tentang penelitian dan tujuannya. Kemudian, peneliti membagikan lembar persetujuan untuk menjadi responden (informed consent) yang ditandangani oleh ibu yang mempunyai anak umur 2-5 tahun. Responden berhak memilih untuk bersedia maupun tidak bersedia menjadi responden penelitian. Jika bersedia menjadi responden maka responden akan menandatangani surat persetujuan menjadi responden yang disaksikan oleh saksi yaitu teman sejawat atau sama-sama teman seangkatan dan jika responden tidak bersedia menjadi responden maka dianggap gugur. Responden yang bersedia maupun yang tidak bersedia menjadi responden tidak akan dibedakan dalam memberikan pelayanannya. Peneliti membantu responden untuk membacakan dan mengisi kuesioner tersebut sesuai dengan jawaban responden.

Setelah mendapatkan persetujuan menjadi responden, maka peneliti akan membacakan dan membantu mengisi kuesioner setiap item pertanyaan yang berisi tentang perilaku sebelumnya, tingkat pendidikan, status sosial ekonomi, manfaat tindakan yang dirasakan, hambatan terhadap tindakan yang dirasakan dan perilaku pencegahan stunting.

\subsection{Analisis}

Penelitian ini menggunakan analisa data deskriptif, bivariat dan multivariat. Analisa deskriptif bertujuan untuk menjelaskan atau mendeskripsikan data karakteristik responden yang meliputi pendidikan terakhir, pendapatan, pekerjaan responden, status perkawinan, jumlah anak, tinggi badan anak, jenis kelamin anak dan umur anak. Analisis bivariat dilakukan untuk tabulasi silang antara masingmasing variable independent dengan variable dependent dengan menggunakan uji chi square. Analisis multivariat bertujuan untuk mengathui variabel bebas mana yang besar pengaruhnya terhadap variabel terikat, variabel bebas yang berhubungan dengan variabel terikat dipengaruhi oleh variabel lain atau tidak, dan bentuk hubungan beberapa variabel bebas dengan variabel terikat membentuk hubungan langsung atau pengaruh tidak langsung. Proses analisis data pada penelitian ini menggunakan uji statistik regresi logistik dengan $\mathrm{p}$ value $<0.05$.

\subsection{Ethical Clearance}

Penelitian ini telah dinyatakan lolos kaji etik dan mendapatkan sertifikat Ethical Approval dengan No. 1203-KEPK yang dikeluarkan oleh Komite Etik Penelitian Kesehatan Fakultas Keperawatan Universitas Airlangga pada tanggal 12 Desember 2018.

\section{Hasil}

Responden memiliki tingkat pendidikan SD yaitu sebanyak $79 \mathrm{ibu}$ (55.9\%) dengan hasil uji hipotesis $(p=0.74)$ tidak berhubungan dengan perilaku pencegahan stunting. Sebagian responden mempunyai status sosial ekonomi $<1.500 .000$ yaitu sebanyak 74 orang $(52.5 \%)$ dan $(p=0.07)$ yang artinya tidak berhubungan dengan perilaku pencegahan stunting. Responden mempunyai perilaku sebelumnya yang cukup yaitu sebanyak 91 orang $(64.6 \%)$ dengan hasil uji hipotesis $(p=0.032)$ berhubungan dengan perilaku pencegahan stunting. Mayoritas responden memiliki manfaat dari tindakan yang dirasakan cukup yaitu sebanyak $65 \mathrm{ibu}$ (46.1\%) dan $(p=0.35)$ tidak berhubungan dengan perilaku 
pencegahan stunting. Mayoritas ibu merasakan hambatan dari tindakan sebanyak 81 ibu (57.9\%) dengan nilai $(\mathrm{p}=0.31)$ tidak berhubungan dengan perilaku pencegahan stunting [Tabel 1].

Hasil analisis multivariat diketahui bahwa perilaku sebelumnya menunjukkan hasil $(\mathrm{p}<0.05)$ dan tingkat pendidikan, status sosial ekonomi, manfaat dari tindakan dan hambatan dari tindakan yang tidak menujukkan hasil signifikan ( $p>0.1$ ). Tabel diatas menunjukkan bahwa tingkat pendidikan yang lebih baik dalam perilaku pencegahan stunting dibandingkan dengan responden yang mengatakan tidak ada manfaat yang telah di berikan. Namun analisis ini tidak menunjukkan hasil yang signifikan $\mathrm{p}=0.34$. Responden yang mengatakan bahwa yang tidak ada hambatan dalam perilaku pencegahan stunting memiliki kecenderungan 1.73 kali lebih baik dibandingkan dengan mereka yang memiliki hambatan. Namun hasil analisis ini tidak menunjukkan hasil yang signifikan $\mathrm{p}=0.31$.

Tabel 1. Hubungan antara tingkat pendidikan, status sosial ekonomi, perilaku sebelumnya, manfaat dari tindakan yang dirasakan dan hambatan dari tindakan dengan perilaku pencegahan stunting pada Desember 2018

\begin{tabular}{|c|c|c|c|c|c|c|c|}
\hline \multirow{2}{*}{ Variabel } & \multirow{2}{*}{ Kategori } & \multicolumn{4}{|c|}{ Perilaku pencegahan stunting } & \multirow{2}{*}{$\Sigma(\%)$} & \multirow[b]{2}{*}{$\mathbf{p}$} \\
\hline & & Negative & $\%$ & Positif & $\%$ & & \\
\hline \multirow{5}{*}{$\begin{array}{l}\text { Tingkat } \\
\text { Pendidikan }\end{array}$} & SD & 28 & 19,8 & 51 & 36,1 & $79(55,9)$ & \multirow{5}{*}{0,74} \\
\hline & SMP & 10 & 7,1 & 18 & 12,8 & $28(19,9)$ & \\
\hline & SMA & 6 & 4,3 & 14 & 10 & $20(14,3)$ & \\
\hline & PT & 3 & 2,1 & 11 & 7,8 & $14(9,9)$ & \\
\hline & Total & 47 & 33,3 & 94 & 66,7 & $141(100)$ & \\
\hline \multirow{3}{*}{$\begin{array}{l}\text { Status Sosial } \\
\text { Ekonomi }\end{array}$} & $<1.500 .000$ & 34 & 24,1 & 40 & 28,4 & $74(52,5)$ & \multirow{3}{*}{0,07} \\
\hline & $>1.500 .000$ & 13 & 9,2 & 54 & 38,3 & $67(47,5)$ & \\
\hline & Total & 47 & 33,3 & 94 & 66,7 & $141(100)$ & \\
\hline \multirow{4}{*}{$\begin{array}{l}\text { Perilaku } \\
\text { sebelumnya }\end{array}$} & Kurang & 1 & 0,7 & 0 & 0 & $1(0,7)$ & \multirow{4}{*}{0,032} \\
\hline & Cukup & 41 & 29,1 & 50 & 35,5 & $91(64,6)$ & \\
\hline & Baik & 5 & 3,5 & 44 & 31,2 & $49(34,7)$ & \\
\hline & Total & 47 & 33,3 & 94 & 66,7 & $141(100)$ & \\
\hline \multirow{4}{*}{$\begin{array}{l}\text { Manfaat dari } \\
\text { tindakan yang } \\
\text { dirasakan }\end{array}$} & Kurang & 10 & 7,1 & 11 & 7,8 & $21(14,9)$ & \multirow{4}{*}{0,35} \\
\hline & Cukup & 29 & 20,5 & 36 & 25,6 & $65(46,1)$ & \\
\hline & Baik & 8 & 5,7 & 47 & 33,3 & 55 (39) & \\
\hline & Total & 47 & 33,3 & 94 & 66,7 & $141(100)$ & \\
\hline \multirow{3}{*}{$\begin{array}{l}\text { Hambatan } \\
\text { dari tindakan }\end{array}$} & Menghambat & 38 & 26,9 & 43 & 30,5 & $81(57,9)$ & \multirow{3}{*}{0,31} \\
\hline & $\begin{array}{l}\text { Tidak } \\
\text { menghambat }\end{array}$ & 9 & 6,4 & 51 & 36,2 & $60(42,6)$ & \\
\hline & Total & 47 & 33,3 & 94 & 66,7 & $141(100)$ & \\
\hline
\end{tabular}

Tabel 2. Hasil analisis multivariat faktor yang berhubungan dengan perilaku pencegahan stunting pada anak usia 2-5 tahun berdasarkan Teori Health Promotion Model (HPM) pada Desember 2018

\begin{tabular}{lcccc}
\hline \multicolumn{1}{c}{ Variabel } & \multirow{2}{*}{ Sig } & \multirow{2}{*}{ Exp(B) } & \multicolumn{2}{c}{ 95\% C.I. for EXP(B) } \\
Lpwer & 0,51 & 2,56 \\
\hline Tingkat pendidikan & 0,74 & 1,14 & 0,93 & 5,21 \\
Status sosial ekonomi & 0,07 & 2,21 & 1,09 & 7,27 \\
Perilaku sebelumnya & 0,03 & 2,81 & 0,54 & 5,51 \\
Manfaat dari tindakan yang & 0,35 & 1,77 & 0,57 & 5,44 \\
dirasakan & 0,31 & 1,73 & & \\
Hambatan dari tindakan & & & & \\
\hline
\end{tabular}

rendah 1.14 kali lebih baik dalam melakukan perilaku pencegahan stunting. Hal ini ditunjukkan dengan hasil tidak signifikan dengan nilai p 0,74 . Status sosial ekonomi menunjukkan bahwa status sosial ekonomi yang tinggi mempunyai 2,30 kali lebih baik melakukan perilaku pencegahan stunting dengan nilai $\mathrm{p}$ 0.07. Hasil analisis pada variabel perilaku sebelumnya menunjukkan bahwa perilaku sebelumnya yang baik mempunyai 2,81 kali lebih baik dalam melakukan perilaku pencegahan dengan nilai p 0,03 . Jadi, perilaku sebelumnya yang lebih baik cenderung lebih baik dalam melakukan perilaku pencegahan stunting dibandingkan dengan perilaku sebelumnya yang buruk [Tabel 2].

Responden yang mengatakan bahwa manfaat dari tindakan itu baik memiliki kecenderungan 1.77 kali

\section{PEMBAHASAN}

4.1 Hubungan tingkat pendidikan dengan perilaku pencegahan stunting

Hasil analisis dalam penelitian ini menunjukkan bahwa setiap ibu yang menjadi responden mayoritas memiliki tingkat pendidikan sekolah dasar (SD). Dari uji regresi logistik, nilai kemaknaan dan korelasinya menunjukkan tidak ada hubungan yang signifikan antara tingkat pendidikan ibu dengan perilaku pencegahan stunting. Hal ini menunjukkan bahwa tingkat pendidikan ibu tidak mempunyai pengaruh terhadap perilaku pencegahan stunting.

Menurut penelitian yang dilakukan (11) dan (12) yang mengatakan bahwa pendidikan ibu tidak 
memiliki hubungan yang signifikan dengan kejadian stunting. Ibu yang berpendidikan tinggi biasanya memiliki pekerjaan dimana akan menyebabkan berkurangnya waktu ibu dalam mengasuh anak sehingga perhatian terhadap pemberian makan pada anak ikut berkurang dan menyebabkan anak menderita kurang gizi, yang selanjutnya berpengaruh buruh terhadap pertumbuhan dan perkembangan anak.

Hal ini berlawanan penelitian (13) yang mengatakan bahwa status pendidikan ibu menjadi prediktor penting stunting di pedesaan Guatemala, namun pendidikan ibu juga dapat dipengaruhi oleh petugas kesehatan yang dapat memberikan informasi kesehatan kepada ibu. Berbeda juga dengan penelitian oleh (14) mengatakan bahwa terdapat hubungan bermakna antara pendidikan ibu dengan kejadian stunting pada balita. Ibu yang berpendidikan lebih cenderung untuk membuat keputusan yang akan meningkatkan gizi dan kesehatan anakanaknya. Selain itu, ibu yang berpendidikan cenderung menyekolahkan semua anaknya sehingga memutus rantai kebodohan, serta akan lebih baik dalam menggunakan strategi demi kelangsungan hidup anaknya, seperti ASI yang memadahi, imunisasi, terapi rehidrasi oral, dan keluarga berencana. Maka dari itu, mendidik wanita akan menjadi langkah yang berguna dalam pengurangan prevalensi malnutrisi terutama stunting. Teori HPM menyatakan bahwa tingkat pendidikan merupakan salah satu sosial budaya dimana faktor ini tidak secara langsung mempengaruhi perilaku pencegahan stunting. Jadi, banyak faktor lain yang juga mempengaruhi perilaku pencegahan stunting misalnya faktor personal yang meliputi faktor biologis dan faktor psikologis.

\subsection{Hubungan status sosial ekonomi dengan perilaku pencegahan stunting}

Hasil analisis dalam penelitian ini menunjukkan bahwa mayoritas status sosial ekonomi responden berada di bawah 1.500.000 dan dari uji regresi logistic disimpulkan bahwa tidak terdapat hubungan antara status sosial ekonomi dengan perilaku pencegahan. Hal ini bertentangan dengan penelitian yang telah dilakukan oleh (9) dan (15)yaitu pendapatan keluarga yang rendah merupakan faktor yang berhubungan dengan kejadian stunting pada balita. Dengan Penghasilan kecil, keluarga akan mempunyai keterbatasan dan kesulitan dalam mencukupi kebutuhan sehari-hari.

Pendapatan keluarga merupakan jumlah uang yang dihasilkan dan jumlah uang yang akan dikeluarkan untuk membiayai keperluan rumah tangga selama satu bulan. Pendapatan keluarga yang mencukupi akan menunjang perilaku anggota keluarga untuk mendapatkan pelayanan kesehatan keluarga yang lebih memadahi (16). Tingkat sosial ekonomi berkaitan dengan daya beli keluarga (17). Kemampuan keluarga untuk membeli bahan makanan antara lain tergantung pada besar kecilnya pendapatan keluarga, harga bahan makanan itu sendiri, serta tingkat pengelolaan sumber daya lahan dan pekarangan. Keluarga dengan pendapatan terbatas kemungkinan besar kurang dapat memenuhi kebutuhan makanannya terutama untuk memenuhi kebutuhan zat gizi dalam tubuh anak. Berdasarkan (18) keterbatasan penghasilan keluarga turut menentukan mutu makanan yang dikelola setiap harinya baik dari segi kualitas maupun jumlah makanan. Kemiskinan yang berlangsung dalam waktu lama dapat mengakibatkan rumah tangga tidak mampu untuk memenuhi kebutuhan pangan yang menyebabkan tidak tercukupinya gizi untuk pertumbuhan anak.

Jumlah anggota keluarga merupakan salah satu faktor yang berpengaruh pada pola pertumbuhan anak dan balita dalam suatu keluarga. Jumlah anggota keluarga yang semakin besar tanpa diimbangi dengan meningkatnya pendapatan akan menyebabkan pendistribusian konsumsi pangan akan semakin tidak merata (19). Status sosial ekonomi keluarga yang rendah bukan berarti keluarga tidak bisa memenuhi kebutuhan pangan sehari-hari. Hal ini dapat dibuktikan jika tidak adanya hubungan antara status sosial ekonomi dengan perilaku pencegahan stunting yang ada di wilayah Puskesmas Galis. Banyak keluarga dengan status sosial ekonomi yang rendah yang berada di Galis dapat memenuhi kebutuhan pangan sehari-hari dengan memanfaatkan sayuran yang ditanamnya sendiri. Menurut (4) bahwa konsumsi sayur-sayuran yang mengandung vitamin, mineral dan serat merupakan salah satu indikator sederhana dalam mewujudkan gizi seimbang.

\subsection{Hubungan perilaku sebelumnya dengan perilaku pencegahan stunting}

Perilaku sebelumnya adalah perilaku yang sering dilakukan dimasa lalu secara langsung maupun tidak langsung yang berdampak kepada kemungkinan perilaku yang meningkatkan status kesehatan (5). Hasil analisis dalam penelitian ini menunjukkan bahwa mayoritas ibu memiliki perilaku sebelumnya yang cukup berupa pemberian makanan tambahan pada ibu hamil, mengatasi kekurangan zat besi dan asam folat, mengatasi kekurangan iodium, menyediakan obat cacing, memberikan imunisasi lengkap, dan melakukan pencegahan dan pengobatan diare sebanyak 91 orang. Dari uji korelasi regresi logistic menunjukkan adanya hubungan antara perilaku sebelumnya dengan perilaku pencegahan.

Hasil tabulasi silang didapatkan hasil bahwa terdapat 11 orang yang mempersepsikan bahwa manfaat dari tindakan yang dirasakan kurang namun memiliki upaya pencegahan stunting yang positif. Namun, jika ditinjau dari distribusi usia responden, sebanyak 7 orang diantaranya berada pada tahap umur 20-30 tahun dan 5 diantaranya berada di tahap lebih dari 30 tahun. Dalam tahap perkembangannya, 20-30 tahun merupakan masa di mana manusia mencapai pada keadaan terbentuknya kemandirian pribadi dan ekonomi. Selain itu, pada tahap usia perkembangan ini mereka mulai bertanggungjawab (20). Selama usia dewasa awal ini kemampuan 
berpikir kritis meningkat dan proses pengambilan keputusan bersifat fleksibel. Hal ini disebabkan karena masa dewasa awal terus berkembang dan harus terlibat dalam perubahan dalam perubahan rumah tangga (21).

Asupan gizi selama kehamilan dan kurang gizi merupakan faktor yang dapat mempengaruhi berat badan lahir rendah (BBLR) (22). BBLR akan mempengaruhi masa dewasa anak dan akan mengalami stunting (23). Berdasarkan penelitian (24) riwayat imuninasi dasar merupakan faktor risiko kejadian stunting dimana responden yang memiliki riwayat imunisasi dasar tidak lengkap mempunyai risiko mengalami stunting dibandingkan dengan responden yang memiliki riwayat imunisasi dasar lengkap. Menurut (25) bahwa pemberian makanan tambahan kurang dari 6 bulan mempunyai 5.5 kali pengaruh yang signifikan terhadap kejadian stunting.

4.4 Hubungan manfaat dari tindakan dengan perilaku pencegahan stunting

Manfaat tindakan secara langsung memotivasi perilaku dan tidak langsung mendetermin rencana kegiatan untuk mencapai manfaat sebagai hasil. Manfaat tadi menjadi gambaran mental positif atau reinforcement positif bagi perilaku. Menurut teori nilai ekspentasi motivasi penting untuk mewujudkan hasil seseorang dari pengalaman dahulu melalui pelajaran observasi dari orang lain dalam perilaku (5).

Berdasarkan distribusi jawaban sebagian besar responden memiliki persepsi manfaat dari tindakan yang dirasakan cukup meliputi peningkatan fungsi kognitif, motorik dan bahasa pada anak dan menurunkan biaya perawatan anak sakit dan juga memiliki perilaku pencegahan stunting yang positif. Hasil penelitian ini menunjukkan bahwa persepsi manfaat dari tindakan yang dirasakan tidak berhubungan dengan perilaku pencegahan stunting yang berarti tingginya persepsi manfaat dari tindakan yang dirasakan tidak membuat seseorang untuk melakukan perilaku pencegahan stunting.

Penelitian ini selaras dengan (26) yang menunjukkan bahwa tidak ada hubungan antara status gizi dengan perkembangan balita. Hasil penelitian ini berbeda dengan penelitian yang dilakukan (27) menyatakan bahwa tugas perkembangan bahasa dan kogntif pada kelompok anak balita stunted lebih rendah dibandingkan anak balita normal dan menunjukkan hubungan yang signifikan antara status gizi indeks (TB/U) dengan perkembangan bahasa pada balita. Menurut penelitian yang dilakukan oleh (28) bahwa pengerdilan pada anak usia dini tidak memiliki hubungan dengan kinerja kognitif anak-anak dikarenakan masih terdapat banyak faktor yang dapat emningkatkan kinerja kognitif anak misalnya lama menyusui, ukuran relatif anak saat lahir, dan masalah kesehatan yang dialami oleh anak.

Berdasarkan uraian diatas kemungkinan pernyataan tentang persepsi manfaat dari suatu tindakan tidak berpengaruh dikarenakan belum adanya kesadaran yang tinggi dari individu untuk menjaga kesehatannya agar tidak terjadi komplikasi dari perilaku pencegahan stunting.

\subsection{Hubungan hambatan tindakan dengan perilaku pencegahan stunting}

Hambatan tindakan adalah kendala selama kegiatan perilaku pencegahan stunting mulai dari masa kehamilan sampai anak berumur 2 tahun. Hambatan tindakan dalam melakukan perilaku pencegahan stunting meliputi akses pada air bersih dan sanitasi, penyediaan bahan pangan, akses pada layanan kesehatan dan jaminan kesehatan, pendidikan pengasuhan orang tua, pendidikan gizi masyarakat, dan jaminan sosial bagi keluarga yang kurang mampu.

Mayoritas responden yang merasa tidak memiliki hambatan dari tindakan memiliki perilaku pencegahan stunting yang positif. Dalam penelitian ini juga didapatkan bahwa responden yang merasa ada hambatan tindakan namun perilaku pencegahan stunting positif. Hasil penelitian tentang hubungan hambatan tindakan yang dirasakan dengan perilaku pencegahan stunting menunjukkan bahwa tidak adanya hubungan antara hambatan dari tindakan dengan perilaku pencegahan stunting.

Sanitasi yang buruk dapat meningkatkan kejadian sakit seperti diare pada balita. Keluarga dengan sanitasi rumah memenuhi syarat sebagian besar memiliki balita yang tidak terkena diare begitu pula sebaliknya dimana akan berpengaruh terhadap anak yaitu menjadi stunting (29). Sanitasi yang buruk merupakan salah satu faktor yang mempengaruhi terjadinya stunting (30). Pada hasil penelitian oleh (31) menunjukkan bahwa proporsi kejadian stunting lebih banyak ditemukan pada responden yang mendapatkan pola asuh yang kurang baik lebih tinggi dibandingkan dengan responden yang mendapatkan pola asuh yang baik jadi dan terdapat hubungan yang signifikan antara pola asuh gizi dengan stunting. Berbeda dengan peneltian yang dilakukan (32) hambatan tindakan yang dirasakan (perceived barrier) secara langsung mempengaruhi perilaku ibu dalam memenuhi perilaku ibu dalam memenuhi kebutuhan gizi anak prasekolah yang berarti semakin ibu mempersepsikan adanya hambtan dalam memenuhi kebutuhan gizi anak, maka secara langsung akan meningkatkan perilaku dalam memenuhi kebutuhan gizi anak prasekolah sesuai dengan kecukupan gizinya.

Hambatan yang dirasakan merupakan suatu kesadaran akan hambatan tindakan yang dapat menimbulkan masalah kesehatan dalam hubungannya denga perilaku kesehatan. Hambatan yang dirasakan bisa dipengaruhi oleh banyak factor salah satunya bisa karena alasan ekonomi. Kesadaran seseorang tentang kesehatan dan perilaku promosi kesehatan dapat terhambat oleh rendahnya pendapatan seseorang sehingga akan berdampak pula terhadap kemampuan seseorang untuk mempertahankan status kesehatan mereka (5). 
Hambatan yang dirasakan atau yang dipersepsikan ibu sangat mempengaruhi niat atau komitmennya untuk berperilaku positif dalam melakukan perilaku pencegahan stunting. Namun, ada beberapa faktor lain yang dapat menyebabkan bahwa ibu yang mempunyai hambatan dari tindakan yang tinggi tidak mempengaruhi perilaku pencegahan stunting misalnya ibu berusaha untuk mencari informasi dari media elektronik dan memanfaaatkan pengalaman ibu balita lain untuk mencari solusi dari hambatan yang mereka hadapi dalam melakukan perilaku pencegahan stunting.

4.6 Faktor yang lebih dominan dengan perilaku pencegahan stunting

Analisis multivariat terhadap variabel tingkat pendidikan, status sosial ekonomi, perilaku sebelumnya, manfaat dari tindakan dan hambatan dari tindakan, terdapat salah satu variabel yang menunjukkan nilai Exp (B) 2,97 yaitu variabel perilaku sebelumnya. Dari hasil tersebut dapat disimpulkan bahwa variabel yang memiliki kecenderungan lebih besar dalam melakukan perilaku pencegahan adalah perilaku sebelumnya. Perilaku sebelumnya menunjukkan bahwa perilaku sebelumnya yang tinggi mempunyai 2,97 kali lebih baik dalam melakukan perilaku pencegahan dengan nilai p 0,03. Jadi, perilaku sebelumnya yang lebih tinggi cenderung lebih baik dalam melakukan perilaku pencegahan. Faktor dominan yang berhubungan dengan stunting adalah pola asuh gizi karena memiliki nilai OR paling besar yaitu 4.571 artinya balita yang mempunyai pola asuh kurang baik berpeluang menjadi stunting sebesar 4.5 kali di bandingkan dengan balita yang mendapatkan pola asuh yang baik. Pola asuh merupakan salah satu faktor yang berperan penting dalam status gizi balita.

Berbeda juga dengan penelitian yang dilakukan oleh (11) bahwa tinggi badan ibu memiliki pengaruh yang paling besar terhadap kejadian stunting dengan nilai OR = 10.31 yang artinya bahwa tinggi badan ibu yang kurang memiliki 10.31 kali terjadinya stunting. Ibu yang pendek merupakan salah satu faktor yang berhubungan dengan kejadian stunting. Salah satu atau kedua orang tua yang pendek akibat kondisi patologi (seperti defisiensi hormone pertumbuhan) memiliki gen dalam kromosom yang membawa sifat pendek sehingga memperbesar peluang anak mewarisi gen tersebut dan tumbuh menjadi stunting. Akan tetapi, bila orang tua pendek akibat kekurangan zat gizi atau penyakit, kemungkinan anak dapat tumbuh dengan tinggi badan normal selama anak tersebut tidak terpapar faktor risiko yang lain.

\section{KESIMPULAN}

Perilaku pencegahan stunting pada anak usia 2-5 tahun berdasarkan Teori Health Promotion Model (HPM) dipengaruhi oleh perilaku sebelumnya (prior related behaviour) yaitu pemberian makanan tambahan pada ibu hamil, mengatasi kekurangan zat besi dan asam folat, mengatasi kekurangan iodium, menyediakan obat cacing, memberikan imunisasi lengkap, dan melakukan pencegahan dan pengobatan diare. Sebagian besar pendidikan ibu yang memiliki anak usia 2-5 tahun di wilayah kerja Puskesmas Galis adalah sekolah dasar (SD). Perilaku sebelumnya yang lebih baik cenderung lebih baik dalam melakukan perilaku pencegahan stunting dibandingkan dengan perilaku sebelumnya yang buruk. Mayoritas ibu di wilayah kerja Puskesmas Galis memiliki manfaat dari tindakan yang dirasakan cukup. Mayoritas ibu yang memiliki anak usia 2-5 tahun di wilayah kerja Puskesmas Galis merasakan hambatan dari tindakan pencegahan stunting.

Dukungan dari petugas kesehatan perlu adanya health education lebih kepada ibu mengenai perilaku pencegahan stunting dengan memanfaatkan posyandu yang diadakan di masyarakat. Serta disarankan untuk mengoptimalisasi program KIA dan Gizi yang berfokus pada perilaku pencegahan stunting. Perlu dilakukan pelatihan terhadap kaderkader posyandu untuk mendampingi ibu-ibu yang kurang pengetahuan mengenai perilaku pencegahan stunting. Sedangkan bagi reponden disarankan untuk menghentikan kebiasaan yang bertentangan dengan kesehatan khususnya dalam perilaku pencegahan stunting seperti mengesampingkan konsumsi susu ibu hamil dan mengurangi konsumsi sayuran hijau selama masa kehamilan.

\section{UCAPAN TERIMA KASIH}

Dengan ini saya mengucapkan terima kasih kepada Badan Kesatuan Bangsa dan Politik Kabupaten Bangkalan, Dinas Kesehatan Kabupaten Bangkalan, Puskesmas Kecamatan Galis, bidan beserta asisten, kader Posyandu dan seluruh responden yang telah memfasilitasi dan sangat membantu dalam penelitian ini. Tak lupa pembimbing yang telah bersedia meluangkan waktu, memberi semangat dan motivasi. Serta kedua orang tua serta adik saya yang selalu memberikan semangat dan dukungan kepada saya.

\section{DAFTAR PUSTAKA}

1. Child WHO, Standards G, W H O. Training Course on Child Growth Assessment. World Heal Organ Train Course Child Growth Assessment Geneva. 2008;WS 103:1-116.

2. MCA Indonesia. Stunting dan Masa Depan Indonesia. Millenn Chall Acc - Indones. 2013;2010:2-5.

3. WHO. What's At Stake. WhoInt. 2014;(9):1-10.

4. Kemenkes. Kementerian $\{$ Kesehatan $\}$ Republik\} \{Indonesia\}. In Kementeria Kesehatan Republik Indonesia; 2017.

5. Pender NJ. Health Promotion in Nursing Practice. 2015.

6. Trihono, Atmarita, Tjandrarini DH, Irawati A, Utami NH, Tejayanti T, et al. Pendek (Stunting) di Indonesia, Masalah dan Solusi. Lembaga 
Penerbit Balitbangkes. 2015. 218 p.

7. Kemenkes. Kementerian Kesehatan Republik Indonesia. August. 2013.

8. Illahi RK, Muniroh L. Gambaran Sosio Budaya Gizi Etnik Madura. Media Gizi Indones. 2016;11(2):135-43.

9. Nadhiroh KN dan SR. Faktor Yang Berhubungan Dengan Kejadian Stunting Pada Balita. J Media Gizi Indones. 2015;10(Faktor yang berhubungan dengan kejadian stunting):13-9.

10. Biro Humas Prov. Jatim. 2017.

11. Nasikhah R. Faktor Risiko Kejadian Stunting Pada Balita. Univ Diponegoro. 2014;1:1-27.

12. Kamal MS. Socio-economic determinants of severe and moderate stunting among under-five children of rural Bangladesh. Malays J Nutr. 2011;17(1):105-18.

13. Sereebutra P, Solomons N, Aliyu MH, Jolly PE. Sociodemographic and environmental predictors of childhood stunting in rural Guatemala. Nutr Res. 2006;26(2):65-70.

14. Wright KO, Shogbamimu Y, Akinbami A, Adebisi R, Senbanjo I, Iolade A. Nutritional status of children in a well-child clinic in Lagos, Nigeria. African J Food, Agric Nutr Dev. 2018;18(03):13602-16.

15. Bomela N. Child nutritional status and household patterns in South Africa. African J Food, Agric Nutr Dev. 2007;7(5):un-un.

16. Manurung JJ, Adler H. Manurung. Ekonomi Keuangan dan Kebijakan Moneter. Pertama. Jakarta: Salemba Empat; 2009.

17. Fikawati $\mathrm{S}$ dan AS. Kajian Implementasi dan Kebijakan Air Susu Ibu Eksklusif dan Inisiasi Menyusu Dini di Indonesia. Makara Kesehat. 2010;14(1):17-24.

18. Fikrina LT, Rokhanawati D. Hubungan tingkat sosial ekonomi dengan kejadian stunting pada balita usia 24-59 bulan di desa Karangrejek Wonosari Gunung Kidul. 2017;1-13.

19. Hapsari W. Hubungan Pendapatan Keluarga Pengetahuan Ibu Tentang Gizi Tinggi Orang Tua Dan Tingkat Pendidikan Ayah Dengan Kejadian Stunting Pada Anak Umur 12-59 Bulan. Skripsi. 2018;300.

20. Santrock J. Adolescence: Perkembangan Remaja. Jakarta: Erlangga; 2003.

21. Potter \& Perry. Fundamental Keperawatan. 2nd ed. Jakarta: EGC; 2006.

22. Sukmawati, Hendrayati, Chaerunnimah, Nurhumaira. Status Gizi Ibu Saat Hamil, Berat Badan Lahir Bayi Dengan Stunting Pada Balita. Media Gizi Pangan. 2018;25(1):18-24.

23. Soetjiningsih. Buku Ajar II Perkembangan Anak dan Remaja. Jakarta: Buku Kedokteran EGC; 2012.

24. Swathma D, Lestari H, Teguh R. Riwayat Imunisasi Dasar Terhadap Kejadian Stunting Pada Balita Usia 12-36 Bulan Di Wilayah Kerja Puskesmas Kandai Kota Kendari Risk Factors Analysis of Low Birth Weight, Body Length At Birth and Basic Immunization History Toward Stunting of Children Aged. 2016;1-10.

25. $\mathrm{Mj} \mathrm{E}$, Cheah WL, Lee PY. Factors Influencing Malnutrition among Young Children in serawak. $2014 ; 20(2)$.

26. Ningrum EW, Utami T. Hubungan Antara Status Gizi Stunting Dan Perkembangan Balita Usia 1259 Bulan. J Bidan. 2017;70-9.

27. Hanum NL, Khomsan A. Pola Asuh Makan, Perkembangan Bahasa, dan Kognitif Anak Balita Stunting dan Normal di Kelurahan Sumur Batu, Bantar Gebang Bekasi. J Gizi dan Pangan. 2012;7(2):81-8.

28. Hassanpour S, Langlotz CP, States U. The effect of early childhood stunting on children's cognitive achievements: Evidence from young lives Ethiopia. Ethiop J Heal Dev. 2017;31(2):29-39.

29. Mayasari D, Indriyani R, Ikkom B, Kedokteran F, Lampung U, Tanjungkarang PK, et al. Stunting , Faktor Resiko dan Pencegahannya Stunting , Risk Factors and Prevention. 2018;5:540-5.

30. Hanifah L, Wulansari R, Meiandayati R, Laksminingsih E. Stunting trends and associated factors among Indonesian children aged 0-23 months : Evidence from Indonesian Family Life Surveys ( IFLS ) 2000, 2007 and 2014. 2018;24(3):315-22.

31. Maywita E. Faktor Risiko Penyebab Terjadinya Stunting Pada Balita Umur 12-59 Bulan Di Kelurahan Kampung Baru Kec . Lubuk Begalung Tahun 2015 Risk Factors Cause the Stunting of Age 12-59 Months in Kampung Baru Kec . Lubuk Begalung in 2015 Erni Maywita Dosen Tetap Fak. J Ris Hesti Medan. 2018;3(1):56-65.

32. Has ES and A. Model pengembangan pemenuhan kebutuhan gizi anak prasekolah berbasis. J Ners. 2012;7(2):121-30. 